\title{
Functional complementation analysis in potato via biolistic transformation with BAC large DNA fragments
}

\author{
Maria Raffaella Ercolano ${ }^{1,2}$, Agim Ballvora ${ }^{1}$, Jürgen Paal ${ }^{1}$, Hans-Henning Steinbiss ${ }^{1}$, \\ Francesco Salamini ${ }^{1}$ and Christiane Gebhardt ${ }^{1, *}$ \\ ${ }^{1}$ Max-Planck Institut für Züchtungsforschung, Carl von Linné Weg 10, 50829 Köln, Germany; ${ }^{2}$ Current \\ address: Department of Soil, Plant and Environment Sciences, Via Universita 100, 80055 Portici, Italy; \\ *Author for correspondence (e-mail: gebhardt@mpiz-koeln.mpg.de; phone: ++49 [0]221 5062 430; fax: ++ \\ 49 [0]221 5062413 )
}

Received 10 September 2002; accepted in revised form 2 May 2003

Key words: BAC, Biolistic transformation, Potato, Phytophthora infestans

\begin{abstract}
Gene isolation from plants by positional cloning frequently requires several rounds of transformation. To reduce the resources invested and to accelerate the process, we have used large DNA fragments in transformation experiments, followed by analysis of transgenic plants to assess functional complementation. Specifically, the transformation of potato with DNA from the $106 \mathrm{~kb}$ BAC plasmid BA87d17 is described. The large fragment was introduced into the potato genome by biolistic transformation, while attempting to clone the $R l$ gene conferring a race specific resistance to Phytophthora infestans. Thirty-one kanamycin resistant plants were regenerated of which thirteen showed the necrotic lesions typical for the hypersensitive response after infection with the incompatible $P$. infestans race 4, which carries the avirulence gene Avrl. The successful complementation supported the location of the $R 1$ gene in the BAC insertion of the BA87d17 plasmid. Based on PCR and Southern gel blot analysis, both complete and incomplete integrations of the large construct into the recipient genome were demonstrated.
\end{abstract}

\section{Introduction}

In plant biology, the modification of the genome by recombinant technologies provides a tool for addressing multiple questions. For this reason, transformation techniques have become routine for many plant species. Agrobacterium-mediated transformation is the most popular method, but other gene delivery systems, among them microprojectile bombardment, have several advantages (Potrykus 1991). This method has made possible, in fact, the stable transformation of important but recalcitrant agricultural species (Christou 1996). Romano et al. (2001) have reported regeneration of transgenic potato plants via particle bombardment.
The introduction and stable integration of DNA fragments of $100 \mathrm{~kb}$ or more into plant genomes is another step forward in transformation technology that could accelerate the map-based cloning and functional characterization of target genes (Shibata and Liu 2000). The construction of high-density molecular linkage maps and the preparation of genomic DNA libraries with insertions of foreign DNA larger than $50 \mathrm{~kb}$ have contributed to the success of the positional cloning strategy. Once a contig of overlapping large insert genomic clones has been assembled for the map region containing a gene of interest, it is necessary to determine by functional complementation which clone in the contig contains the target gene. This task requires transformation experiments 
with all DNA sequences in the contig that cannot be separated from the target gene by recombination events. When the target locus resides in a chromosomal region with low recombination frequency and/or a low level of DNA polymorphism, several hundred $\mathrm{kb}$ of sequence may have to be tested for functional complementation. These experiments are very laborious and time consuming when stable transformation cannot be circumvented by transient transformation assays. Complementation analysis using large DNA fragments, like those represented by whole BAC (Bacterial Artificial Chromosome) clones, could contribute to overcome this problem. In addition, transformation with large DNA fragments allows simultaneous transfer of two or more genes, thus facilitating the molecular analysis of complex traits. Such transformation technologies could be particularly helpful to associate quantitative agronomic traits with specific genes via map-based cloning (Lukowitz et al. 2000).

Whereas plant transformation with DNA fragments up to circa $20 \mathrm{~kb}$ is routine, success in stable plant transformation with DNA fragments larger than $50 \mathrm{~kb}$ is limited. Hamilton et al. (1996) reported stable integration of $150 \mathrm{~kb}$ of human DNA in the tobacco genome by Agrobacterium-mediated transformation with a binary BAC vector. A TAC (transformationcompetent artificial chromosome) binary vector was used for Agrobacterium-mediated transformation of Arabidopsis with large DNA fragments (Liu et al. 1999; Sawa et al. 1999; Sato et al. 2001). Biolistic transformation with whole BAC DNA offers an alternative method for transferring large DNA fragments into plant genomes. Tobacco transgenic plants have been obtained after biolistic transformation with up to $230 \mathrm{~kb}$ of cotton DNA cloned in the pBACwich vector (Choi et al. 2000). We examined the feasibility of this approach in potato by using a functional assay, which was the hypersensitive response conferred by the $R l$ gene for resistance to late blight. A physical map has been constructed in the region harboring $R l$ and the minimal tiling path consisted of several overlapping BAC clones, containing inserts with an average size of $80 \mathrm{~kb}$. Based on genetic and sequencing data, the BAC clone BA87d17 was the best candidate for hosting the $R 1$ gene (Ballvora et al. 2002). The whole plasmid DNA of BA87d17 was used for complementation analysis of the $R I$ resistance phenotype in stably transformed potato plants. The results reported here demonstrate that a DNA fragment with a size of about $106 \mathrm{~kb}$ can be stably integrated into the potato genome via biolistic transformation. In addition, we show that transgenic plants expressed the race specific hypersensitive resistance to Phytophthora infestans, as expected when the $R l$ gene is present in the BAC DNA.

\section{Materials and Methods}

Plant material and test for resistance to Phytophthora infestans

The potato cultivar Desirée, susceptible to Phytophthora infestans, was used in all transformation experiments. The $P$. infestans resistant clone $\mathrm{H} 79.1506 / 1$ (Rlrl) referred to as P41 in LeonardsSchippers et al. (1992) was the source of the $R l$ gene and was used as $R l$ resistant control.

P. infestans race 4 (Avrl, avr4) and race 1,4 (avrl, avr4) were kindly provided by Dr. Francine Govers, Wageningen University, The Netherlands. Resistance was determined as described by Ballvora et al. (2002). Plants with clear hypersensitive resistance response were classified as HR (Figure $1 \mathrm{~B}, \mathrm{C}$ ) and fully susceptible plants as S (Figure 1A). Plants with phenotypes intermediate between full resistance and susceptibility were classified as URS (unclear resistance status). After inoculation of detached leaves from this group of transgenic plants with $P$. infestans race 4 , low and inconsistent hyphae formation was observed.

\section{Plasmids}

The large insert plasmid, the BAC clone BA87d17 carrying the putative $R l$ gene (Ballvora et al. 2002), the vector pCLD04541 (Jones et al. 1992) used to construct the large insert BAC library and plasmid pAHC25 bearing the gusA gene (Christensen et al. 1996) were the source of DNA for biolistic transformation. BAC plasmid DNA was isolated using the QIAfilter Plasmid Purification Kit 100 (Qiagen, Hilden, Germany) according to manufacturer's instructions, with some modifications (Ballvora et al. 2002) and used for bombardment without linearization.

\section{Transformation via particle gun}

Twenty-five to thirty $\mu \mathrm{g}$ DNA of BA $87 \mathrm{~d} 17$ were bombarded onto detached leaves. The DNA was 


\section{Race4 (Avr1,avr4) Race1,4 (avr1, avr4)}

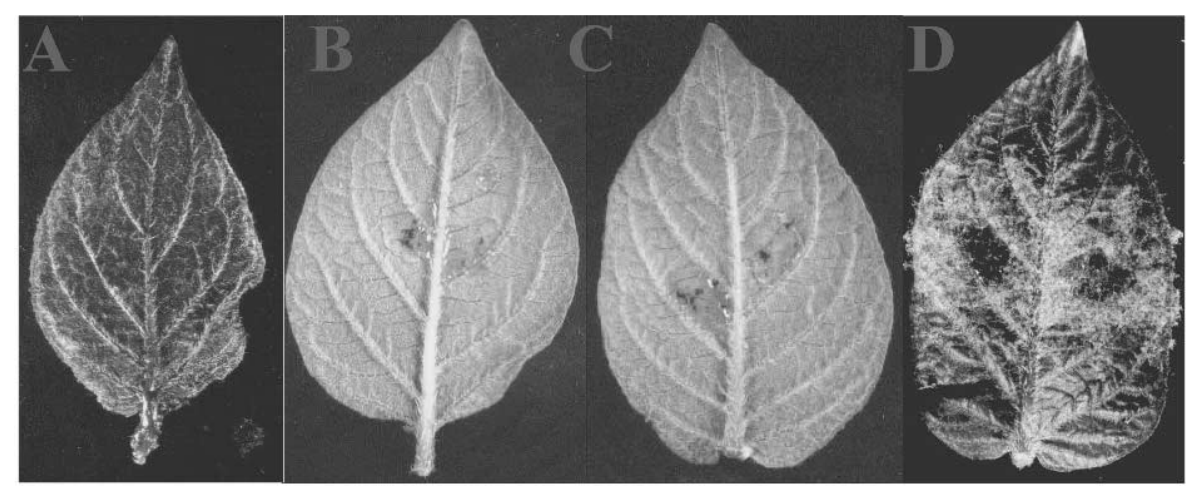

Figure 1. Complementation of the Phytophthora infestans (Avrl) susceptible variety Desirée via biolistic transformation with the BAC clone BA87d17 carrying the $R 1$ resistance gene. Plant-pathogen interaction responses are shown 9 days post-inoculation with $P$. infestans race 4 (Avrl, avr4) on leaflets from (A) untransformed Desirée ( 1 1r1r1r1) - phenotype: S; (B) transgenic Desirée transformed with plasmid BA87d17 - phenotype: HR; (C) the resistant line P41 (RIrl) that was the source of the R1 gene - phenotype: HR; and (D) the same transgenic plant as (B) infected with $P$. infestans race 1,4 (avrl, avr4) - phenotype: S.

coated to $2 \mathrm{mg}$ of gold resuspended in ethanol. Microprojectile bombardment was carried out using a helium-driven BioRad PDS-1100/He (Bio-Rad, Richmond, CA, USA) following the instructon protocol. A disc-rupture pressure of 1100 psi and a vacuum pressure of 27.5 inches of mercury were applied. The distance between the stopping screen and the Petri dishes containing target plant material was approximately $6 \mathrm{~cm}$. The diameter of the bombarded area was circa 2-2.5 cm. Leaves of three to four weeks old Desirée shoots grown in vitro were used for transformation. Several small leaves laying on MS medium without kanamycin within the bombarded area were bombarded and cultivated for 24 hours at $24{ }^{\circ} \mathrm{C}$ with 16 hours light. The following day leaves were transferred onto MS1 medium containing $300 \mu \mathrm{g} / \mathrm{ml}$ kanamycin and after one week onto MS2 medium in the presence of the same amount of kanamycin. Leaves were further incubated until the formation of microcalli was observed. The microcalli were transferred onto kanamycin-containing (300 $\mu \mathrm{g} / \mathrm{ml})$ MS3 medium to induce the regeneration of shoots (RochaSosa 1989).

Two days after bombardment with vector pAHC25 containing the gusA reporter gene, leaves were analyzed for transient GUS expression (Gallagher 1994) by counting the number of blue spots under a microscope.

\section{Isolation of total genomic DNA and Southern gel blot analysis}

Potato genomic DNA was isolated as described (Oberhagemann et al. 1999). For Southern gel blot analysis, $5 \mu \mathrm{g}$ total DNA were digested to completion with HindIII. Fragments were separated on a $0.9 \%$ agarose gel. The gel was processed and blotted onto a membrane (PALL, Biodyne, Portsmouth, UK), according to Sambrook et al. (1989). Filter hybridization with a radioactive labeled probe was as described by Gebhardt et al. (1989). The probe was about $1 \mathrm{~kb}$ in length and comprised the coding DNA sequence of the $R l$ gene from position 1575 to 2630 , including the leucine-rich-repeats (LRR) domain (Ballvora et al. 2002).

\section{Polymerase Chain Reaction analysis}

Polymerase Chain Reaction was performed according to standard protocols (Saiki et al. 1985). For PCR analysis, small scale plant genomic DNA was prepared using the DNeasy-Kit (Qiagen, Hilden, Germany) according to the manufacturer's instructions with modifications. One hundred $\mathrm{mg}$ fresh plant material were ground by vortexing for a few seconds in a $2 \mathrm{ml}$ plastic tube containing two metal beads. After adding AP2 buffer, the mixture was incubated for 15 $\min$ on ice and then for $30 \mathrm{~min}$ at $-70{ }^{\circ} \mathrm{C}$. Primer sequences used for PCR analysis are listed in Table 3. The annealing temperature was $55^{\circ} \mathrm{C}$ in all PCR 
Table 1. Biolistic transformation of $S$. tuberosum cv Desirée with the plasmids BA87d17 (vector plus 77 kb potato DNA insertion) and pCLD04541 (vector control; 29kb)

\begin{tabular}{|c|c|c|c|c|c|c|c|c|}
\hline \multirow[t]{2}{*}{$\begin{array}{l}\text { Experi- } \\
\text { ment }\end{array}$} & \multirow[t]{2}{*}{ Plasmid } & \multirow[t]{2}{*}{$\begin{array}{l}\text { No. of kanamycin } \\
\text { resistant plants }\end{array}$} & \multicolumn{3}{|c|}{ No. of plants tested for resistance } & \multicolumn{3}{|c|}{$\begin{array}{l}\text { No. of plants characterized molecu- } \\
\text { larly }\end{array}$} \\
\hline & & & HR & $\mathrm{S}$ & $\mathrm{URS}^{1}$ & HR & $\mathrm{S}$ & URS \\
\hline A & BA87d 17 & 2 & 1 & 0 & 1 & 1 & 0 & 1 \\
\hline \multirow[t]{2}{*}{ B } & BA87d17 & 26 & 11 & 7 & 8 & 10 & 2 & 5 \\
\hline & pCLD04541 & 2 & & & & & & \\
\hline \multirow[t]{2}{*}{$\mathrm{C}$} & BA87d17 & 3 & 1 & 1 & 1 & 1 & 1 & 0 \\
\hline & pCLD04541 & 3 & & & & & & \\
\hline \multirow[t]{2}{*}{ Total } & BA87d17 & 31 & 13 & 8 & 10 & 12 & 3 & 6 \\
\hline & pCLD04541 & 5 & & & & & & \\
\hline
\end{tabular}

(1) URS = plants with partial resistance status (see materials and methods).

reactions. The PCR product obtained by primers $122 \mathrm{~A}$ and $122 \mathrm{~B}$ was transformed into a CAPS marker: the 450 bp product amplified from Desirée was digested by MseI in two fragments of 200 and $250 \mathrm{bp}$, whereas the fragment of BA87d17 did not contain the MseI recognition site (data not shown). The $R 1$ specific primers 76-2sf2 and 76-2SR have been described elsewhere (Ballvora et al. 2002).

\section{Results}

Transformation of potato $c v$ Desirée with the large insert plasmid BA87d17

Production of transgenic plants (cv Desirée) with the BAC clone BA87d17 was carried out via biolistic transformation. The shooting efficiency was assessed by bombardment of young potato leaves with gold particles coated with DNA from plasmid pAHC25 carrying the gusA reporter gene. Two days after bombardment, the leaves were analyzed for GUS expression. Between 250 and 300 blue spots per shot were counted in several experiments, a frequency sufficient to allow the selection of kanamycin resistant calli when using a plasmid containing the nptII gene.

Under the same conditions as adopted for the control plasmid pAHC25, three biolistic transformation experiments (A to $\mathrm{C}$ in Table 1) were carried out, each consisting of several bombardments with whole plasmid DNA of BAC clone BA87d17. This plasmid has an insertion of $77 \mathrm{~kb}$ of potato DNA in the pCLD04541 vector which has a size of $29 \mathrm{~kb}$. The vector alone carrying the kanamycin resistance nptII gene was used in equimolar DNA amounts as control for the transformation efficiency in experiments B and C.

The three transformation experiments are summarized in Table 1. In total, thirty-one kanamycin resistant plants were regenerated from calli appearing with low frequency in three independent transformation experiments with BA87d17 DNA.

\section{Complementation of the $R 1$ resistance phenotype after biolistic transformation}

Leaves of kanamycin resistant plants were tested for response to infection with $P$. infestans race 4 (Avrl, avr4) (Figure 1). Of 31 plants tested, 13 reproducibly showed the same hypersensitive response (HR) (Figure $1 \mathrm{~B}$ ) that was observed when line P41 carrying the $R 1$ resistance gene was inoculated with the same race (Figure 1C). Two HR plants originated from experiments $\mathrm{A}$ and $\mathrm{C}$ while the remaining eleven HR plants were from experiment B (Table 1). Eight plants were susceptible $(\mathrm{S})$, while the remaining ten plants were of intermediate susceptibility, showing an unclear phenotypic response to infection (URS in Table 1). The 13 transgenic plants that showed hypersensitive resistant to $P$. infestans race 4 (Avrl, avr4) showed a susceptible response upon inoculation with race 1,4 (avrl, avr4) (Figure 1D). It was concluded that about 40 percent of the transgenic plants transformed with the $106 \mathrm{~kb}$ plasmid BA87d17 were functionally complemented for the $R I$ resistance phenotype.

\section{Molecular analysis of BA87d17 transgenic plants}

Twenty-one transgenic plants representing the phenotypic categories HR, S and URS (Table 1) were characterized by PCR to assess the extent to which the 


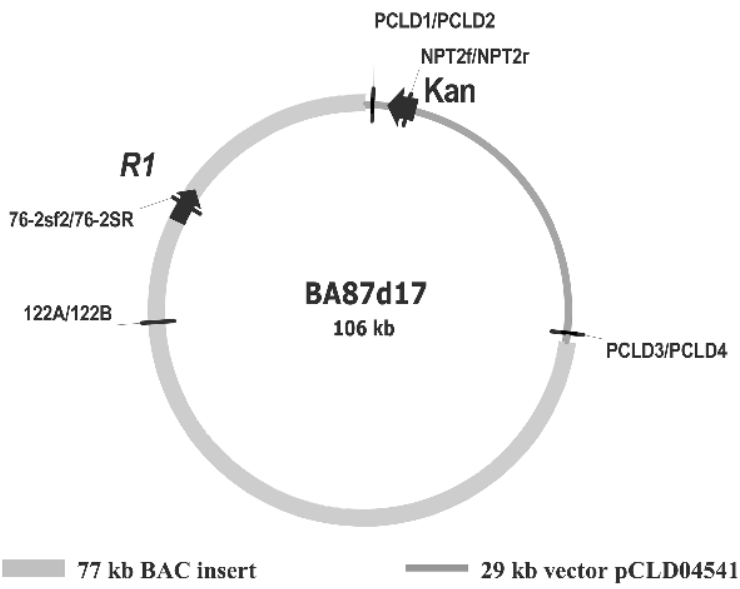

Figure 2. Schematic representation of plasmid BA87d17 (106 kb) showing the position of DNA sequences amplified by PCR. The DNA fragments used to characterize the transgenic potato lines were amplified with primers CLPD1/CLPD2 (position $400 \mathrm{bp} \mathrm{5'}$ after the pCLD04541 - insert junction; NPT2r/NPT2f (2400 bp); CLPD3/CLPD4 (28,000 bp); 122A/122B (78,000 bp); c762sf2/ c76-2SR (88,000 bp).

BA87d17 DNA was present in the potato genome. Leaf DNA was amplified by the polymerase chain reaction (PCR) using specific primers designed for five different segments of the $106 \mathrm{~kb}$ construct (Figure 2). The primers 76-2sf2 and 76-2SR amplified part of the Rl resistance gene (Ballvora et al. 2002). Primers $122 \mathrm{~A}$ and 122B amplified a fragment of the BA87d17 insertion other than $R 1$ (Figure 2). The three primer pairs CPLD1 / CPLD2, CPLD3 / CPLD4 and NPT2r / NPT2f, were designed based on sequence information of the vector on both sides of the cloning site and of the neomycine phospho-transferase gene (nptII), respectively. Based on resistance phenotype and presence or absence of the five PCR products, the plants fell into eight different groups (Table 2). As expected, all plants were positive for the nptII specific PCR marker. All HR plants (groups I to IV in Table 2) had also the $R l$ specific PCR product. HR plants of groups II, III and IV lacked one or both of the amplification products derived from the vector borders, indicating an incomplete integration of the DNA sequences used for biolistic transformation.

The susceptible plants showed two different patterns. Plants in group V lacked all PCR products except the NPTII marker, whereas the plants in group VI showed all three vector specific amplicons but none of those derived from the BAC clone. Plants with unclear resistance status were positive for all PCR markers, similarly to those of group I (Table 2), with the exception of one plant (group VIII) that lacked one of the BAC insertion specific PCR products.

Southern gel blot analysis confirmed the correlation between the HR phenotype and integration of the $R 1$ gene. DNA from HR and S transgenic plants, untransformed Desirée, clone P41, the donor of the $R 1$ gene and plasmid BA87d17 carrying $R 1$ was digested with HindIII restriction enzyme and hybridized with an $R 1$ probe (Figure 3 ). The probe hybridized to several genomic fragments in all potato genotypes, indicating that $R 1$ is a member of a gene family. Plasmid BA87d17 that carries in addition to the $R l$ gene a second member of the gene family (Ballvora et al. 2002) showed a $9 \mathrm{~kb}$ HindIII fragment as was expected from the $R 1$ genomic sequence (Ballvora et al. 2002) and an additional $3 \mathrm{~kb}$ fragment corresponding to the second gene. The $9 \mathrm{~kb}$ HindIII fragment (marked by an arrow in Figure 3) was present in the $R 1$ donor line $\mathrm{P} 41$ and in all HR plants tested, and was absent in untransformed Desirée and in susceptible plants.

\section{Discussion}

Results described in this paper provide an important contribution to gene cloning and characterization in a major crop. The results we have obtained indicate that biolistic transformation is a suitable strategy to produce transgenic plants carrying large DNA fragments. Mullen et al. (1998) and Choi et al. (2000) have reported biolistic transformation of tobacco plants using YAC DNA from the fungus Cochliobolus heterostrophus and BAC DNA from cotton, respectively. In these papers, however, the functionality of the DNA that was integrated into the tobacco genome was not tested. Here we show that a resistance gene included in a BAC DNA was capable of complementing in a race specific way a susceptible genotype of potato. Out of 31 plants regenerated from three independent transformation experiments, 13 showed the necrotic lesions typical for the HR response after infection with the incompatible $P$. infestans race 4.

While the results we report here clearly support the possibility of functionally evaluating large DNA inserts in complementation tests, it is not clear whether the $106 \mathrm{~kb}$ DNA of BA87d17 were completely transferred without any DNA rearrangements, at least for the eight resistant plants included in group I that were positive for all PCR markers tested (Table 2). The 
Table 2. Extent of BA87d17 integration in transgenic plants representing the phenotypic categories HR (hypersensitive resistant), S (fully susceptible) and URS (unclear resistance status). Plants were analyzed by PCR using five primer pairs positioned in BA87d17 as reported in Figure 2. Plus (+) and minus (-) indicate presence and absence, respectively, of the specific PCR fragment

\begin{tabular}{|c|c|c|c|c|c|c|}
\hline $\begin{array}{l}\text { Transgenic plant groups (No. of plants per } \\
\text { group) }\end{array}$ & $\begin{array}{l}\text { Resistance } \\
\text { phenotype }\end{array}$ & $\begin{array}{l}76-2 \mathrm{sf} 2 / \\
76-2 \mathrm{SR}\end{array}$ & $122 \mathrm{~A} / 122 \mathrm{~B}$ & CPLD1/CPLD2 & $\begin{array}{l}\text { CPLD3/ } \\
\text { CPLD4 }\end{array}$ & NPT2r/NPT2f \\
\hline I (8) & HR & + & + & + & + & + \\
\hline II (1) & HR & + & + & - & + & + \\
\hline III (1) & HR & + & + & - & - & + \\
\hline IV (2) & HR & + & + & + & - & + \\
\hline $\mathrm{V}(1)$ & $S$ & - & - & - & - & + \\
\hline VI (2) & $\mathrm{S}$ & - & - & + & + & + \\
\hline VII (5) & URS & + & + & + & + & + \\
\hline VIII (1) & URS & + & - & + & + & + \\
\hline
\end{tabular}

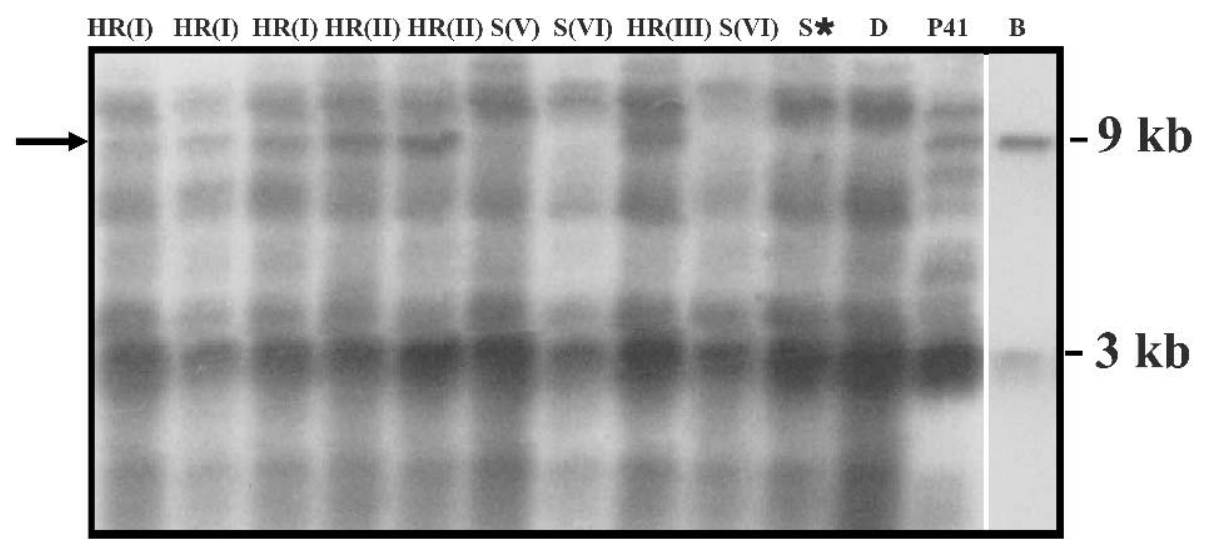

Figure 3. Southern gel blot analysis of BA87d17 transformed Desirée plants. DNA of transgenic hypersensitive resistant (HR) and susceptible (S) plants, of untransformed Desirée (D); line P41 (donor of the R1 gene) and BAC BA87d17 (B) were digested with HindIII, transferred to nylon membrane and hybridized to a $R 1$ probe. The group to which the line belongs according to Table 2 is shown in parenthesis. The susceptible plant marked with * was not analysed by PCR. The R1 specific $9 \mathrm{~kb}$ HindIII fragment present in all HR plants, in P41 and in BA87d17 is indicated by the arrow. The fragment sizes (in kilobases) are shown on the right.

available data suggest, nevertheless, that at least a large part of a complex plasmid can be transferred in plants, using the biolistic transformation procedure. Agrobacterium-mediated transformation can also transfer large DNA inserts: up to $150 \mathrm{~kb}$ of human DNA were transferred, for instance, to the tobacco genome (Hamilton et al. 1996). Liu et al. (1999) have reported functional complementation in Arabidopsis with fragments between 40 to $80 \mathrm{~kb}$ via Agrobacterium transformation using the TAC (transformationcompetent artificial chromosome) binary vector. However, the biolistic transformation offers a simpler approach to the evaluation of BAC-clones for the presence of candidate genes.

From 31 transgenic plants, while 13 showed the typical HR response after infection with $P$. infestans race 4 , the others were fully susceptible or expressed an intermediate resistance phenotype. Failure of the transgene to complement the resistance phenotype can be due to various reasons and is commonly observed in transgenic plants produced via Agrobacterium tumefaciens (Whitham et al. 1994; Grant et al. 1995; Ballvora et al. 2002). Incomplete DNA integration, fragmentation or rearrangements either during the bombardment process or during and after DNA integration into the plant genome can result in transgenic plants that are not complemented. Such events are likely to be present in several of the transgenic lines where one or more PCR products indicative for presence of five different DNA segments of the plasmid BA87d17 were absent. The expression of the HR was strictly correlated with the presence of a PCR product and a genomic HindIII fragment specific for the $R l$ resistance gene. Five URS transgenic lines that 
Table 3. Primer sequences used in PCR analyses

\begin{tabular}{|c|c|c|c|}
\hline Primer & Sequence $\left(5^{\prime}-3^{\prime}\right)$ & Size of PCR product $(\mathrm{bp})$ & $\begin{array}{l}\text { Location }(\mathrm{kb}) \text { of amplified sequences } \\
\text { in BA87d17 (Figure 2) }\end{array}$ \\
\hline PCLD1 & agt gag ggt taa ttt cga gct tgg & 750 & 0.4 \\
\hline PCLD2 & agg tgt tgc tga ctc atc cca ggc & 750 & 0.4 \\
\hline NPT2r & $\begin{array}{l}\text { aag aag gcg ata gaa ggc gat } \\
\text { gcg }\end{array}$ & 700 & 2.400 \\
\hline NPT2f & tcg get atg act ggg cac aac ag & 700 & 2.400 \\
\hline PCLD3 & $\begin{array}{l}\text { geg tta ccc aac tta atc gec ttg } \\
\text { cag ca }\end{array}$ & 500 & 28.000 \\
\hline PCLD4 & gtg aaa tgg gct gca ctc c & 500 & 28.000 \\
\hline $122 \mathrm{~A}$ & gta gtt gag aat agg agg cet aac & 400 & 78.000 \\
\hline $122 \mathrm{~B}$ & ctg cta tca taa atg ata ggc aag & 400 & 78.000 \\
\hline $76-2 s f 2$ & cac tcg tga cat atc ctc act a & 1,400 & 88.000 \\
\hline 76-2SR & caa ccc tgg cat gcc acg & 1,400 & 88.000 \\
\hline
\end{tabular}

did not clearly express the HR had, nevertheless, all PCR products expected for a complete BA87d17 plasmid, including the $R I$ specific fragment (group VII plants in Table 2). Small rearrangements not detected by the PCR analysis, the position effect of the plasmid integration (Allen et al. 1993), co-suppression (Matzke and Matzke 1995) or DNA methylation (Mayer et al. 1993) are possible reasons for this finding.

Biolistic transformation with large insert plasmid DNA facilitated the identification of the $R l$ resistance gene starting with a physical map of about $200 \mathrm{~kb}$ (Ballvora et al. 2002). Alternative strategies available to us were: (I) subcloning and individual complementation analysis of smaller DNA fragments from each BAC spanning the candidate region; (II) increasing the genetic resolution across the candidate region to reduce the size of the physical map to be tested for complementation. Both approaches would have been more laborious and time consuming, particularly when transient complementation assays are not available, as it is the case for testing against resistance to $P$. infestans.

Biolistic transformation has been reported to be successful in a variety of plant species, including several that are not amenable to Agrobacterium-mediated transformation (Potrykus 1991). Therefore, the transfer of large DNA fragments and the complementation analysis of the transgenic lines is likely to work not only in potato but also in other plant species that can be regenerated from in vitro cultures. Application of this strategy could accelerate the functional analysis of single genes or complex loci and the positional cloning of plant specific genes.

\section{Acknowledgements}

This work was supported by the Max-Planck society and the German Ministry for Research and Technology (BMBF grant 0311791). The technical assistance of Heike Henselewski and Sabine Schulze is gratefully acknowledged.

\section{References}

Allen G.C., Hall G.E., Childs L.C., Weissinger A.K., Spiker S. And Thompson W.F. 1993. Scaffold Attachment Regions Increase Reporter Gene Expression in Stably Transformed Plant Cells. Plant Cell 5: 603-613.

Ballvora A., Ercolano M.R., Weiß J., Meksem K., Bormann C.A., Oberhagemann P., Salamini F. and Gebhardt C. 2002. The R1 Gene for Potato Resistance to Late Blight (Phytophthora infestans) Belongs to the Leucine Zipper/NBS/LRR Class of Plant Resistance Genes. The Plant Journal 30(3): 351-361

Choi S., Begum D., Koshinsky H., Ow D.W. and Wing R.A. 2000. A new approach for the identification and cloning of genes: the pBACwich system using Cre/lox site-specific recombination. Nucl. Acids Res. 28(7): 19e

Christensen A.H. and Quail P.H. 1996. Ubiquitin promoter-based vector for high-level expression of selectable and/or screenable marker genes in monocatyledonous plants. Transgenic Research 5: 213-218

Christou P. 1996. Transformation technology. Trends Plant Sci. 1: 423-431

Gallagher S.R. 1994. GUS-Protocols: Using GUS Gene as a Reporter of Gene Expression. Academic Press Inc.

Gebhardt C., Ritter E., Debener T., Schachtschabel U., Walkemeier B., Uhrig U. and Salamini F. 1989. RFLP analysis and linkage mapping in Solanum tuberosum. Theor. Appl. Genet. 78: 65-75.

Grant M.R., Godiard L., Straube E., Ashfield T., Lewald J., Sattler A., Innes R.W. and Dangl J.L. 1995. Structure of the Arabidopsis RPM1 gene enabling dual specificity disease resistance. Science 269: 843-846. 
Hamilton C.M., Frary A., Lewis C. and Tanksley S.D. 1996. Stable transfer of intact high molecular weight DNA into plant chromosomes. Proc. Nat. Acad. Sci. USA 93: 9975-9979.

Jones D.A., Thomas C.M., Hammond-Kosack K.E., Balint-Kurti P.J. and Jones D.J.G. 1992. Effective vectors for transformation, expression of heterologous genes, and assaying transposon excision in transgenic plants. Transgenic Research 1: 285-297.

Leonards-Schippers C., Gieffers W., Gebhardt C. and Salamini F. 1992. The R1 gene conferring race-specific resistance Phytophthora infestans in potato is located on chromosome V. Mol. Gen. Genet. 233: 278-283

Liu Y.-G., Shirano Y., Fukaki H., Yanai Y., Tasaka M., Tabata S. and Shibata D. 1999. Complementation of plant mutants with large genomic DNA fragments by a transformation-competent artificial chromosome vector accelerates positional cloning. Proc. Natl. Acad. Sci. USA 96: 6535-6540

Lukowitz W., Gillmor C.S. and Scheible W.-R. 2000. Positional cloning in Arabidopsis. Why it feels good to have a Genome Initiative working for you. Plant Physiology 123(3): 795-805.

Matzke M.A. and Matzke A.J.M. 1995. How and Why Do Plants Inactivate Homologous (Trans)genes. Plant Physiol. 107: 679718.

Mayer P., Heidemann I. and Niedendorf I. 1993. Differences in DNA-methylation are associated with a paramutation phenomenon in transgenic petunia. Plant Journal, 4: 89-100.

Mullen J., Adam G., Blowers A. and Earle E. 1998. Biolistic transfer of large DNA fragments to tobacco cells using YACs retrofitted for plant transformation. Mol. Breed. 4: 449-457.

Oberhagemann P., Chatot-Balandras C., Bonnel E., Schäfer-Pregl R., Wegener D., Palomino C., Salamini F. and Gebhardt C. 1999. A genetic analysis of quantitative resistance to late blight in potato: Towards marker assisted selection. Mol. Breed, 5: 399-415.

Potrykus I. 1991. Gene transfer to plants: assessment of published approaches and results. Briggs. W.R. (Ed.), Annu. Rev. Plant Physiol. Plant Mol. Biol. 205-226.
Rocha-Sosa M., Sonnewald U., Frommer W., Stratmann M., Schell J. and Willmitzer L. 1989. Both developmental and metabolic signals activate the promoter of a class I patatin gene. The EMBO Journal 8(1): 23-29.

Romano A., Raemakers K., Visser R. and Mooibroek H. 2001. Transformation of potato (Solanum tuberosum) using particle bombardment. Plant Cell Reports 20: 198-204.

Saiki R.K., Gelfrand D.H., Stoffel S., Scharf S.J., Higuchi R., Horn G.T., Mullis K.G. and Ehrlich H.A. 1988. Primer directed enzymatic amplification of DNA with a thermostable DNA polymerase. Science 239: 487-491.

Sambrook J., Fritsch E.F. and Maniatis T. 1989. Molecular Cloning: A laboratory Manual. Cold Spring Harbor, NY: Cold Spring Harbor Laboratory Press.

Sato S., Kato T., Kakegawa K., Ishii T., Liu Y.-G., Awano T., Takabe K., Nishiyama Y., Kuga S., Sato S., Nakamura Y., Tabata S. and Shibata D. 2001. Role of the Putative Membrane-Bound Endo-1,4-ß-Glucanase KORRIGAN in Cell Elongation and Cellulose Synthesis in Arabidopsis thaliana. Plant \& Cell Physiology 42(3): 251-263

Sawa S., Watanabe K., Goto K., Kanaya E., Morita E.H. and Okada K. 1999. Filamentous Flower, a meristem and organ identity gene of Arabidopsis, encodes a protein with a zinc finger and HMG-related domains. Genes \& Development 13: 1079-1088

Shibata D. and Liu Y.-G. 2000. Agrobacterium-mediated plant transformation with large DNA fragments. Trends in Plant Science 5: 354-357

Whitham S., Dinesh-Kumar S.P., Choi D., Hehl R., Corr C. and Baker B. 1994. The product of the tobacco mosaic virus resistance gene N: Similarity to Toll and the interleukin-1 receptor. Cell 78: 1101-1115. 